\title{
KEANEKARAGAMAN JENIS GASTROPODA DI KAWASAN HUTAN MANGROVE DI KELURAHAN SETAPUK BESAR KOTA SINGKAWANG
}

\author{
(The Diversity of Gastropods In the Mangrove ForestArea of Setapuk Besar Village \\ Singkawang City)
}

\author{
Mardi, M. Sofwan Anwari, Burhanuddin \\ Fakultas Kehutanan Universitas Tanjungpura Pontianak. Jl. Daya Nasional Pontianak 78124 \\ E-mail: cidang82@gmail.com
}

\begin{abstract}
Mangrove Surya Perdana Mandiri is a conservation forest area that has a positive impact on the environment and fauna habitat. The main purpose of planting or reforestation in the Surya Perdana Mandiri mangrove forest area is that there are concerns about the high level of abrasion and environmental damage, so mangrove planting in the coastal area, especially the Setapuk Besar Village, Singkawang North Subdistrict. Gastropods is a group of shelled invertebrates and has the main characteristic of using its legs to walk. Gastropoda is a group of animals from mollusc phyla that can live on the type of substrate from coarse to fine. This study aims to examine the diversity of gastropods in the Surya Perdana Mandiri mangrove forest in Setapuk Besar Village, Singkawang Utara Subdistrict. The research method used the survey method. Determination of the location of gastropod research was carried out based on Purposive sampling technique. The results of observations carried out were 8 species consisting of 5 families. Line 1 consists of 63 individuals in line 2 consisting of 86 individuals and line 3 consists of 74 with individual totals of 223. Diversity index of line 1 with value $H^{-}=0.52$, line 2 with value $H^{-}=0.56$ and path 3 with the value $H^{-}=0.62$. Based on these values, species diversity $(H \overline{)}$ in each research line is categorized as having low diversity.
\end{abstract}

Keywords: Diversity, Gastropods, Surya Perdana Mandiri Mangrove

\section{PENDAHULUAN}

Gastropoda merupakan kelompok hewan invertebrata yang bercangkang dan memiliki sifat utama yaitu memanfaatkan kakinya untuk berjalan.Gastropoda adalah kelompok hewan dari filum moluska yang dapat hidup pada jenis substrat dari yang kasar sampai halus.Pesebaran hewan ini hampir di seluruh pantai di Indo-pesisir dan hidup sebagai hewan makrozoobhentos yang hidup di permukaan substrat dan didalam substrat (infauna) (Suwignyo, 2005).

Gastropoda merupakan salah satu moluska yangbanyak ditemukan di berbagai substrat, hal ini karena gastropoda memiliki kemampuan adaptasi yanglebih tinggi dibandingkan dengan kelas yang lain. Moluska memiliki peranan penting bagi lingkunganperairan yaitu sebagai bioindikator lingkungandan kualitas perairan serta sumber makanan bagihewan lain. Bagi manusia, moluska merupakan sumbermakanan bergizi, sebagai obat, sebagai bahan dasarindustri contohnya, cangkang Gastropoda dan Bivalviadapat dipakai sebagai kancing baju (Dharma, 1988).

Kelas gastropoda umumnya lebih dikenal dengan sebutan siput atau keong 
dan termasuk pada filum Moluska. Gastropoda mempunyai sebaran luas dan kemampuan adaptasi terhadap lingkungan sangat beragam, seperti dapat hidup pada daerah daratan, perairan tawar, laut, substrat berpasir dan berlumpur (Nybakken, 1992; Kusrini, 2000). Gastropoda memiliki spesies paling beragam dan terbesar karena berhasil menempati berbagai macam habitat dan ekosistem seperti, ekosistem lamun, ekosistem karang dan ekosistem mangrove (Cappenberg, 2006).

Hutan mangrove atau disebut juga hutan bakau adalah hutan yang tumbuh di daerah air payau dan dipengaruhi oleh pasangsurut air laut.Hutan ini tumbuh khususnya di tempat-tempat terjadinya pelumpuran tanah maupun di sekitar muara sungai yang terjadi pengendapan lumpur yang dibawa air dari hulu dan dari gempuran ombak pantai.Tanaman mangrove memiliki ciri akar yang menyembul kepermukaan, penampakan mangrove seperti hamparan semak belukar yang memisahkan daratan dengan laut.Hutan mangrove juga menjadi habitat bagi satwa liar dan memberikan perlindungan yang kuat terhadap angin yang kuat dan gelombang yang dibangkitkan oleh angin dan juga gelombang tsunami.

Mangrove sebagai habitat merupakansumber alam yang kaya sebagai ekosistem tempat bermukimnya berbagai flora dan fauna. Keragaman flora dan fauna tersebut mulai dari perkembangan mikro organisme seperti bakteri dan jamur yangmemproduksi detritus yang dapat dimakan larva ikan dan hewan-hewan laut kecillainnya. Berbagai hewan seperti, reptil, hewan ampibi, mamalia, datang dan hidupwalaupun tidak seluruh waktu hidupnya dihabiskan di habitat mangrove. Berbagai jenis ikan, ular, serangga, burung, mamalia dapatbermukim di sini.Substrat atau tanah daerah mangrove juga dimanfaatkan sebagai habitat berbagai moluska salah satunya gastropoda. Gastropoda juga memanfaatkan batang mangrove bagian bawah sebagai habitatnya.

Data informasi mengenai keberadaan serta keanekaragaman biota di kawasan hutan mangrove Surya Perdana Mandiri Kelurahan Setapok besar Kecamatan Singkawang Utara belum memadai. Penelitian tentang "Keanekaragaman Jenis Gastropodadi Kawasan Hutan Mangrove Surya Perdana Mandiri Kelurahan Setapok besar Kecamatan Singkawang Utara" perlu dilakukan.

\section{METODE PENELITIAN}

Penelitian ini dilakukan pada bulan juli selama \pm 3 minggu di kawasan hutan mangrove Surya Perdana Mandiri Kelurahan Setapuk Besar Kecamatan Singkawang Utara yang mempunyai luasan \pm 21 Ha. Penelitian dilakukan pada pagi hari ketika air surut sekitar jam 07:00 sampai selesai (menyesuaikan kondisi di lapangan). Alat dan bahan yang digunakan dalam penelitian ini adalah peta lokasi, meteran, tali rapia, pisau, atk, buku 
identifikasi, kertas label, botol sampel, tally sheet. Objek penelitian adalah gastropoda yang ada di kawasan hutan mangrove Surya Perdana Mandiri Kelurahan Setaouk Besar Kota Singkawang.

Metode yang digunakan dalam penelitian ini adalah metode survei, yaitu metode penelitian yang tidak melakukan perubahan/perlakuan khusus terhadap variabel yang akan diteliti dengan tujuan untuk memperoleh serta mencari keterangan secara faktual tentang objek yang diteliti. Data yang digunakan dalam penelitian adalah data primer dan data sekunder.Penentuan lokasi penelitian gastropoda dilakukan berdasarkan teknik Purposive sampling.
Purposive sampling merupakan teknik pengambilan sampel secara sengaja yang digunakan apabila sampel yang diambil mempunyai pertimbangan tertentu (Fachrul, 2007). Pertimbangan yang digunakan dalam penelitian ini adalah garis pantai mulai adanya vegetasi. Penentuan lokasi penelitian dilakukan berdasarkan teknik Purposive sampling. Penentuan jalur berdasarkan hasil survei lapangan yang telah dilakukan yaitu mulai dari garis pantai sampai ditemukannya vegetasi.

Penelitian ini terdapat 3 jalur, setiap jalur terdiri ada 10 petak dengan ukuran $1 \times 1$ meter.Jarak antara tiap-tiap petak yaitu sepanjang 30 meter dan jarak antar jalur 30 meter.

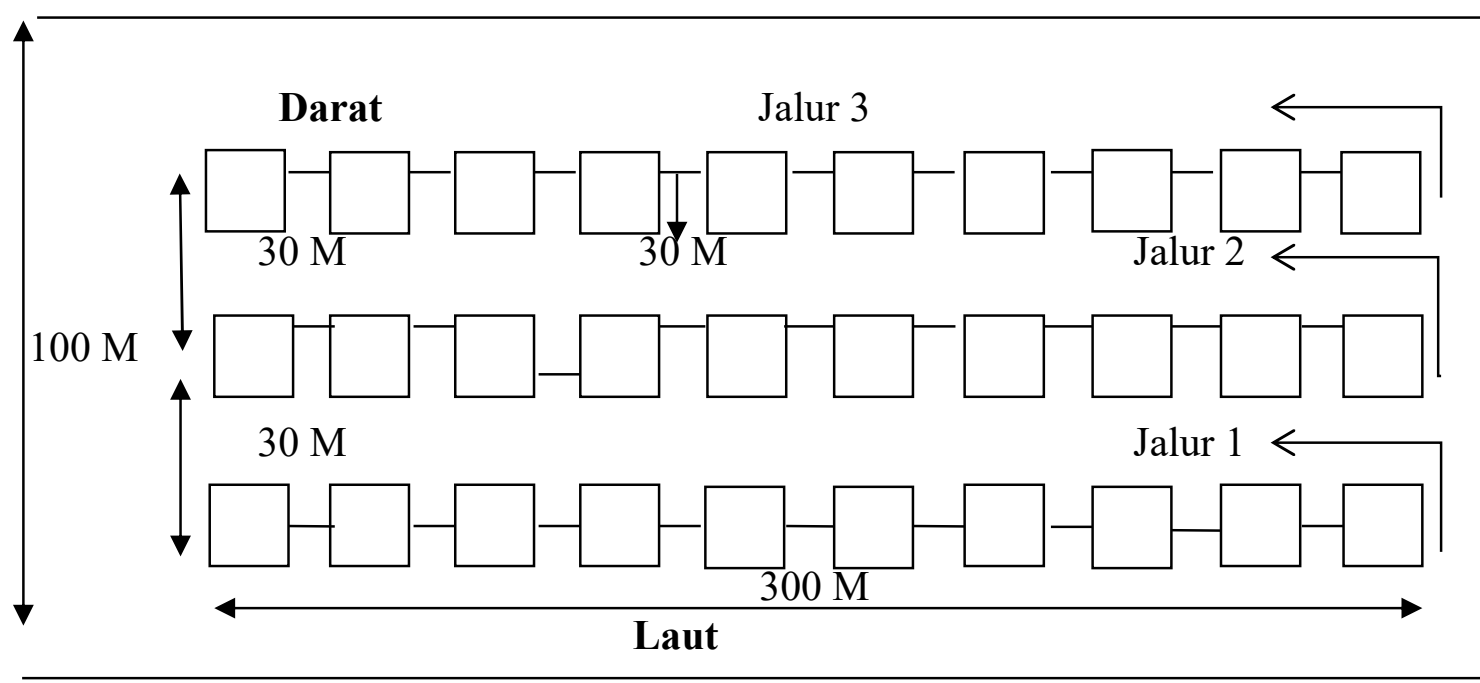

Gambar 1.Bagan Jalur Pengambilan Sampel Gastropoda Di Kawasan MangroveSurya Perdana Mandiri. (Chart of Pathway for Taking Gastropod Samples in the Surya Perdana Mandiri Mangrove Area)

\section{Analisis Data}

Indeks Keanekaragaman Jenis

Keanekaragaman ditentukan

berdasarkan indeks keanekaragaman

(Shannon-Wiener, 1963 dalam Fachrul,

2007), dengan rumus :

$\mathrm{H}^{\prime}=-\Sigma($ pi $\log \mathrm{pi})$
Nilai Pi dipeoleh dengan menggunakan rumus :

$\mathrm{pi}=\frac{n i}{N}$

Keterangan :

$\mathrm{N}=$ Jumlah total Individu 
ni = Jumlah Individu dalam setiap spesies

\section{Kelimpahan Jenis dan Relatif}

Kelimpahan Jenis

Kelimpahan diartikan sebagai satuan jumlah individu yang ditemukan per satuan luas. Menurut Fachrul (2007) perhitungan kelimpahan jenis gastropoda dapat di rumuskan sebagai berikut:

$$
\mathrm{Ki}=\frac{n i}{A}
$$

Keterangan:

$\mathrm{Ki}=$ Kelimpahan jenis (individu/m2)

$\mathrm{ni}=$ Jumlah individu dari spesies ke-i (individu)

$\mathrm{A}=$ Luas area pengamatan $(\mathrm{m} 2)$

Kelimpahan Relatif

Kelimpahan relatif dihitung dengan rumus kelimpahan relatif menurut Fachrul (2007) sebaga berikut :

$\mathrm{KR}=\frac{n i}{N} x 100 \%$

Keterangan :

$\mathrm{KR}=$ Kelimpahan Relatif (\%)

$\mathrm{Ni}=$ Jumlah individu dari spesies ke-i (individu)

$\mathrm{N}=$ Jumlah individu dari seluruh spesies (individu)

Indeks Kemerataan Jenis

Kemerataan jenis digunakan untuk mengetahui gejala dominansi diantara setiap jenis dalalm suatu lokasi. Rumus yang digunakan untuk menghitung nilai Evannes (Odum,1993) adalah :

$\mathrm{E}=\frac{H}{\operatorname{InS}}$

Keterangan :

$\mathrm{E}=$ indeks kemerataan jenis
$\mathrm{H}=$ Indeks keanekaragaman jenis

$\mathrm{S}=$ Jumlah spesies

Indeks Dominansi

Indeks dominansi untuk menunjukkan adanya jenis biota tertentu yangmendominansi di perairan. Dominansi biota tertentu ini diketahui dengan indeksdominansi Simpson, yaitu menggunakan rumus:

$\mathrm{C}=\Sigma$ Pi2 Dimana: $\mathrm{Pi}=\mathrm{ni} / \mathrm{N}$

$\mathrm{C}$ : Indeks Dominansi

ni : jumlah individu spesies ke-i

$\mathrm{N}$ : jumlah individu seluruh spesies

Indeks Kesamaan Jenis

Indeks kesamaan jenis digunakan untuk mengetahui beberapa jenis yang sama pada tiga jalur berbeda.

$$
\mathrm{S}=\frac{3 D}{A+B+C}
$$

Keterangan :

$\mathrm{S}=$ Indeks kesamaan jenis

$A=$ Jumlah jenis pada jalur 1

$\mathrm{B}=$ Jumlah jenis pada jalur 2

$\mathrm{C}=$ Jumlah jenis pada jalur 3

$\mathrm{D}=$ jumlah jenis yang sama pada jalur

A, B dan C

HASIL DAN PEMBAHASAN

Komposisi Jenis Gasropoda di Setiap Jalur Penelitian

Berdasarkan hasil penelitian bahwa jenis-jenis gastropoda yang terdapat pada kawasan hutan mangrove Surya Perdana Mandiri Kelurahan Setapuk Besar Kota Singkawang terdiri atas 5 famili dan 8 spesies.Guna lebih jelas dapat dilihat pada tabel 1 sebagai berikut : 
Vol. 7 (1) : 379 - 389

Tabel 1. Rekapitulasi Jumlah Gastropoda yang terdapat di setiap jalur penelitian. (Recapitulation of the number of gastropods found in each research pathway)

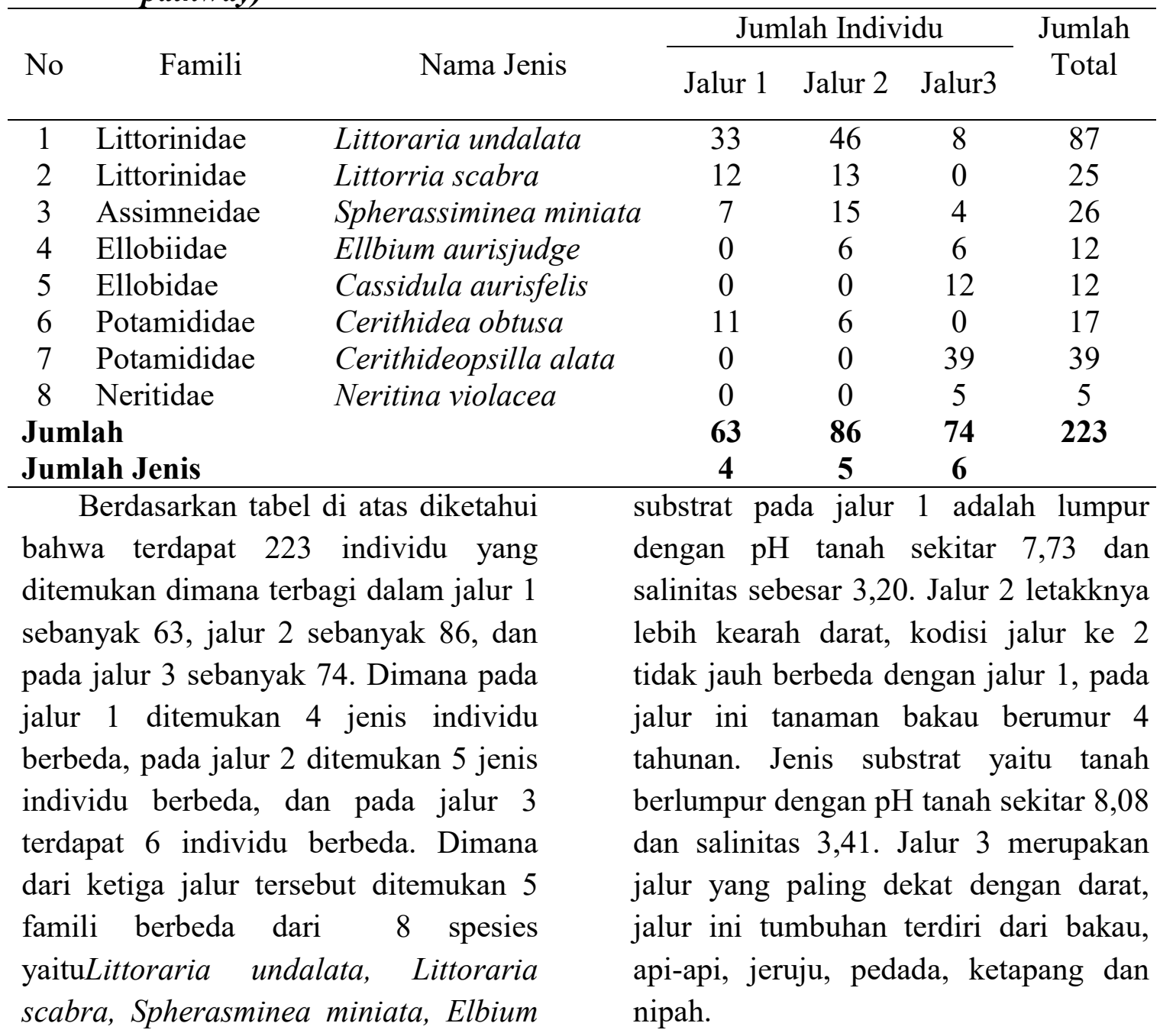

aurisjudge, Cassidula aurifelis,

Cerithidea obtusa, Cerithideopsilla alata dan Neritina violacea .

Jalur 1 merupakan jalur yang paling dekat dengan laut, pada jalur ini gastropoda ditemukan pada permukaan tanah, akar, batang dan daun.Tanaman bakau pada jalur ini berumur sekitar 2 tahunan. Jalur ini terdapat tumbuhan api-api dan tanaman bakau. Jenis

\section{Kelimpahan Jenis}

Kelimpahan jenis merupakan jumlah individu suatu jenis per satuan luas dalam suatu komunitas. Kelimpahan jenis Gastropoda dihitung berdasarkan banyaknya individu di setiap jalur penelitian yang berada pada Kawasan Hutan Mangrove Surya Perdana Mandiri Kelurahan Setapuk Besar Kecamatan Singkawang Utara. 
Tabel 2. Rekapitulasi Kelimpahan Jenis Gastropoda pada Jalur 1 Di Kawasan Hutan Mangrove Surya Perdana Mandiri (Recapitulation of Gastropod Abundance on Track 1)

\begin{tabular}{|c|c|c|c|c|c|}
\hline \multirow[t]{2}{*}{ No } & \multirow[t]{2}{*}{ Famili } & \multirow[t]{2}{*}{ Nama Jenis } & $\begin{array}{c}\text { Jumlah } \\
\text { Individu }\end{array}$ & $\begin{array}{l}\text { Kelimpahan } \\
\text { Individu }\end{array}$ & $\begin{array}{c}\text { Kelimpahan } \\
\text { Relatif }\end{array}$ \\
\hline & & & Jalur 1 & $\mathrm{~A}=\mathrm{X}_{\mathrm{i}} / \mathrm{m}^{2}$ & $\%$ \\
\hline 1 & Littorinidae & Littoraria Undalata & 33 & 3.3 & 52.38 \\
\hline 2 & Littorinidae & Littorria Scabra & 12 & 1.2 & 19.05 \\
\hline 3 & Assimneidae & Spherassiminea Miniata & 7 & 0.7 & 11.11 \\
\hline 4 & Potamididae & Cerithidea Obtusa & 11 & 1.1 & 17.46 \\
\hline & jumlah & & 63 & 6.3 & 100 \\
\hline \multicolumn{3}{|c|}{ Jumlah Jenis } & \multicolumn{3}{|c|}{4} \\
\hline \multicolumn{3}{|c|}{ Hasil perhitungan kelimpahan } & \multirow{5}{*}{\multicolumn{3}{|c|}{$\begin{array}{l}3,3 / \mathrm{m}^{2} \text { dengan kelimpahan relative } \\
52.38 \% \text {. Kelimpahan jenis Gastropoda } \\
\text { pada jalur } 2 \text { di kawasan hutan mangrove } \\
\text { Surya Perdana mandiri dapat dilihat }\end{array}$}} \\
\hline \multirow{4}{*}{\multicolumn{3}{|c|}{$\begin{array}{l}\text { individu pada jalur } 1 \text {, dengan nilai } \mathrm{A}= \\
6.3 \text {, diketahui bahwa kelimpahan } \\
\text { individu terbesar adalah Littoraria } \\
\text { Undalata dengan } 33 \text { individu atau }\end{array}$}} & & & \\
\hline & & & & & \\
\hline & & & & & \\
\hline & & & & & \\
\hline
\end{tabular}

Tabel 3. Rekapitulasi Kelimpahan Jenis Gastropoda pada jalur 2(Recapitulation of Gastropod Species Abundance On track 2)

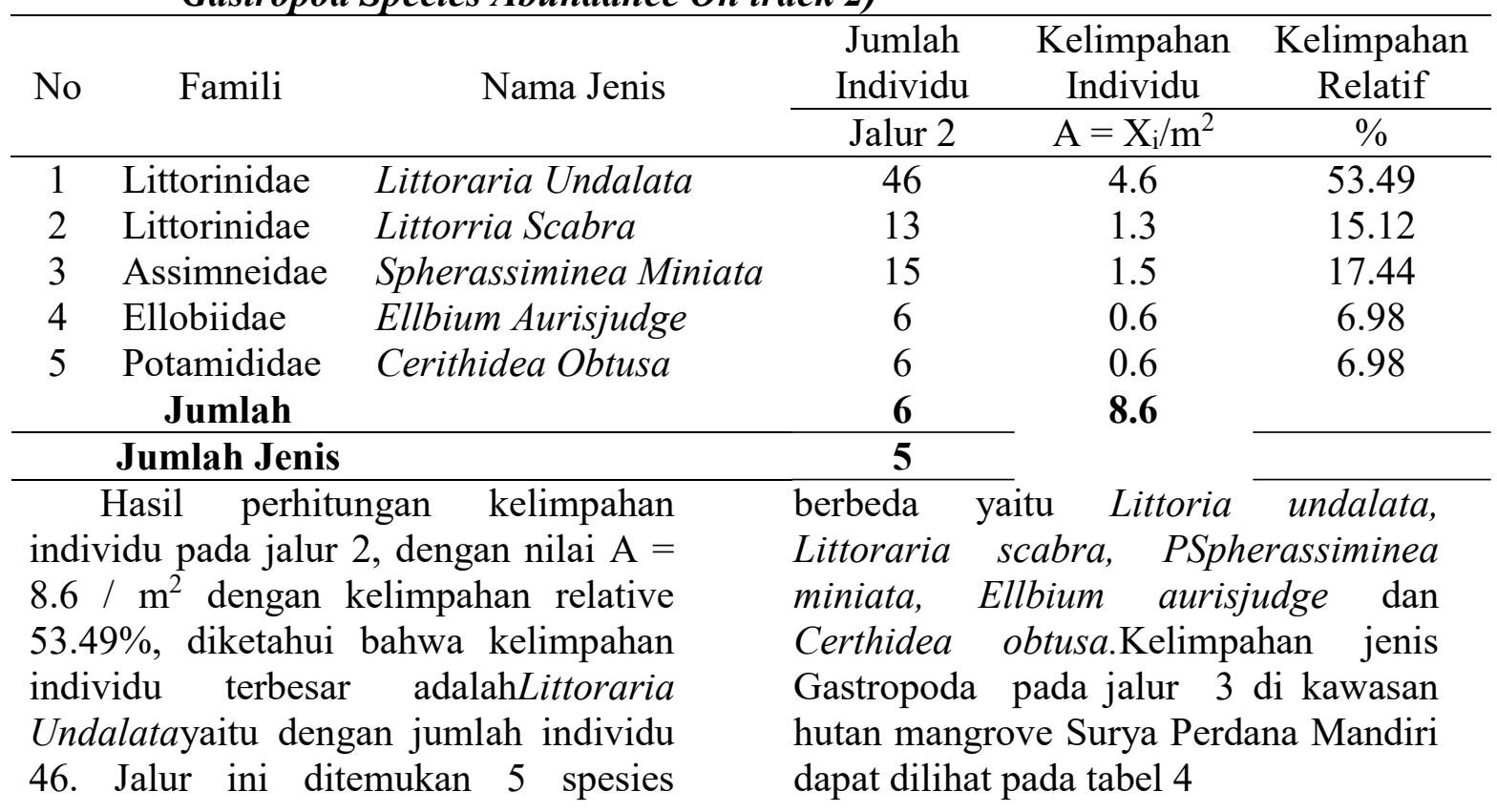


Vol. 7 (1) : 379 - 389

Tabel 4. Rekapitulasi Kelimpahan Jenis Gastropoda pada Jalur 3 Di Kawasan Hutan Mangrove Surya Perdana Mandiri. (Recapitulation of Gastropod species abundance on Track 3)

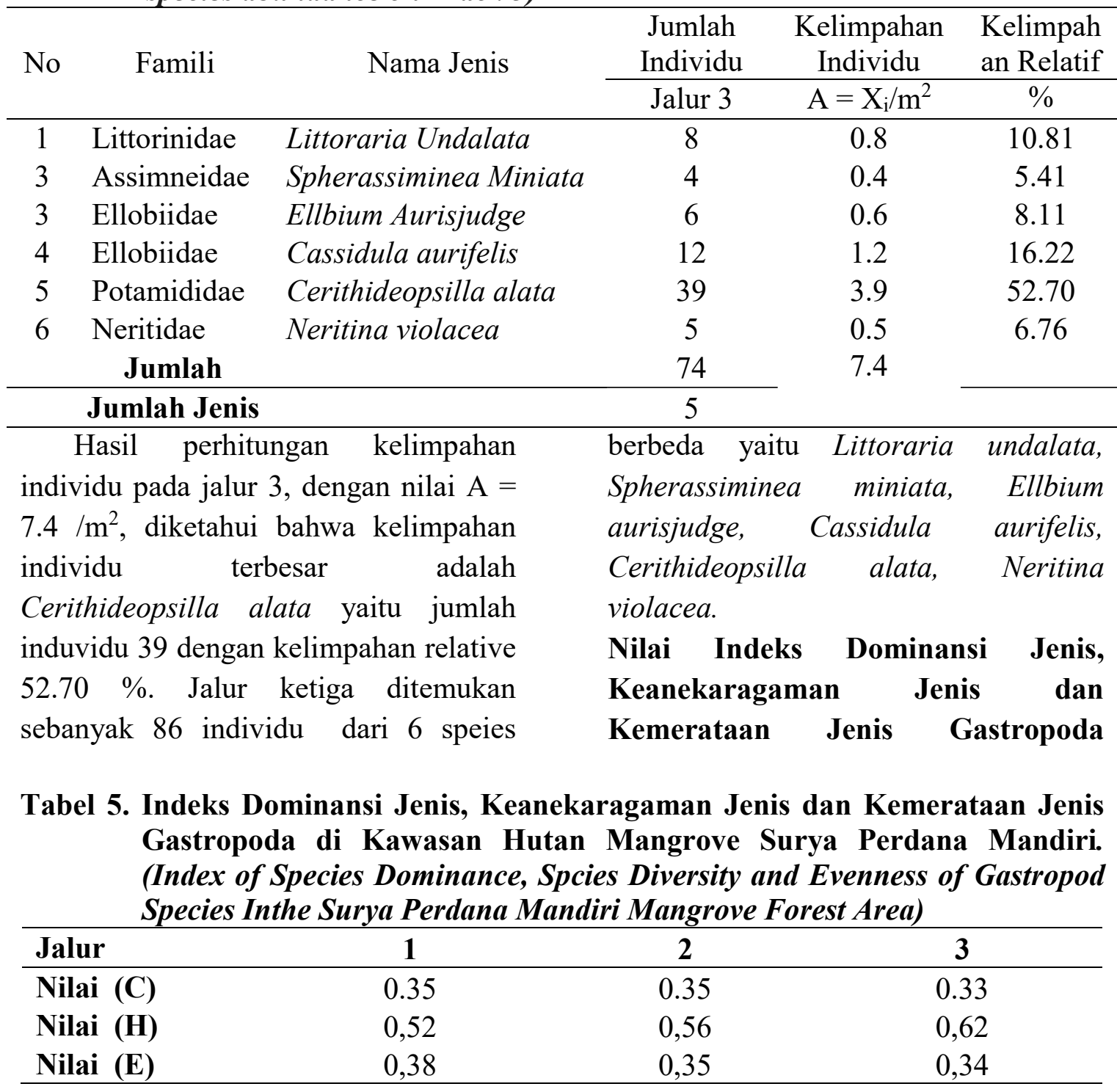

Indeks dominansi menunjukan adanya jenis biota tertentu yang mendominasi di suatu kawasan tertentu. Kisaran nilai indeks dominansi yaitu $00,0<\mathrm{C} \leq 0,30$ artinya dominansi rendah, $0,30<\mathrm{C} \leq 0,60$ artinnya dominansi sedang, dan jika $0,60<\mathrm{C}$ $\leq 1,00$ artinya dominansi tinggi (Simpson's Indeks). Faktor utama yang mempengaruhi jumlah organisme, keragaman jenis dan dominansi antara lain adanya perusakan habitat alami seperti pengkonversian lahan, pecemaran kimia dan organik, serta perubahan iklim. Menurut Odum (1993) Nilai indeks dominansi mendekati $0-1$. Nilai indeks dominansi mendekati $0(\mathrm{C}<0,5)$ maka tidak ada jenis yang mendominasi jenis lainnya dan apabila nilai indeks dominansi 
mendekati $1(\mathrm{C}>1)$ berarti ada jenis yang mendominansi jenis lainnya. Berdasarkan nilai dan kriteria di ketiga jalur penelitian terlihat bahwa nilai indeks dominansi jenis (C) mendekati 0 $(\mathrm{C}<0,5)$ berarti tidak ada jenis yang mendominasi jenis lainnya atau struktur komunitas dalam keadaan tidak stabil.

Keanekaragaman disebut juga dengan keheterogenan jenis. Indeks keanekaragaman menunjukkan adanya kekayaan spesies dalam komunitas dan keseimbangan dalam pembagian jumlah per individu. Kisaran nilai indeks keanekaragaman jenis menurut Shannor-Wiener yaitu $\quad H^{\prime}<1$ keanekaragaman rendah, $\quad 1<\mathrm{H}^{\prime}<3$ keanekaragaman sedang, $\mathrm{H}^{\prime}>3$ keanekagaman tinggi. Hasil analisa nilai indeks keanekaragaman jenis pada Tabel 5 di atas setiap jalur penelitian memiliki nilai keanekaragaman yang berbeda-beda. Kenekaragaman jenis meggambarkan tingginya tingkat keanekaragaman yang terdapat pada suatu kawasan.Semakin tinggi nilai indeks keanekaragaman jenis $(\bar{H})$, maka semakin banyak jenisjenis yang terdapat pada kawasan tersebut. Menurut Shanon Wiener dalam Ferianita (2007), kisaran keanekaragaman jenis $(\bar{H})$ antara 1-3. Kisaran nilai $\bar{H}<1$ berarti keanekaragaman rendah, jika $1<\bar{H}<3$ berarti keanekaragaman sedang dan jika $\bar{H}>3$ berarti keanekaragaman tinggi. Hasil perhitungan indeks keanekaragaman jenis $\bar{H}$ gastropoda di setiap jalur penelitian memiliki nilai yang berbeda-beda diantaranya jalur 1 dengan nilai $\bar{H}=0,52$, jalur 2 dengan nilai $\bar{H}=0,56$ dan jalur 3 dengan nilai $\bar{H}=0,62$. Berdasarkan nilai tersebut keanekaragaman jenis $(\bar{H})$ di setiap jalur penelitian dikategorikan memiliki keanekaragaman rendah karena satwasatwa liar khususnya gastropoda dipengaruhi oleh kerapatan vegetasi yang tinggi seperti api-api (Avicennia marina), bakau (Rhizophora stylosa) dan nipah (Nypa fruticans).Nilai keanekaragaman jenis menunjukan semua di bawah angka 1 yaitu kriteria rendah. Salah satu penyebab rendahnya tingkat keanekaragaman jenis Gastropoda di kawasan hutan Mangove Surya Perdana Mandiri yaitu hutan mangrove ini merupakan hutan tanaman, dimana tingkat kerapatan dan jenis vegetasi yang sangat rendah.

Kemerataan jenis digunakan untuk mengetahui gejala dominansi diantara setiap jenis dalalm suatu lokasi. Kemerataan merupakan komposisi individu tiap spesies yang terdapat dalam komunitas. Kisaran niai indeks kemerataan yaitu $\mathrm{E}>0,6$ artinya kemerataan tinggi, jika $0,4<\mathrm{E}<0,6$ maka kemeraan sedang dan jika nilai $\mathrm{E}$ $<4$ artinya kemerataan rendah (Pielou's Evennes Indek.). Indeks kemerataan jenis menunnjukan kelimpahan individu merata atau tidak. Nilai kemerataan lebih kecil dari 0.4 maka dinyatakan rendah, sedangkan apabila lebih besardari 0.6 maka keseragaman tinggi.Hasil analisis kemerataan (E) pada tiap jalur berkisar dari $0.34-0.38$ jadi tiap jalur memiliki kemerataan yang rendah. Kriteria ini menunjukan 
bahwa tidak ada sebaran yang merata dan menunjukan ada dominansi spesies tertentu pada jalur tertentu. Keanekaragaman jenis dalam suatu komunitas cenderung akan rendah apabila secara fisik terkendali oleh manusia (Odum 1993). Kedua tegakan yang diamati merupakan tanaman homogen hasil budidaya manusia.Krebs (1989) menjelaskan, bahwa jika nilai indeks kemerataan (e) mendekati nilai 1 maka tidak ada jenis yang mendominasi dan penyebaran jumlah individu setiap jenis merata. Gastropoda pada jalur penelitian di hutan Mangrove Surya Perdana Mandiri persebarannya dipengaruhi oleh kondisi lingkungan seperti tipe tekstur tanah, suhu, $\mathrm{pH}$ dan salinitas air.

\section{Indeks Kesamaan Jenis}

Perbedaan juga terlihat dikomposisi nilai kesamaan jenis gastropoda, dari hasil pengamatan pada jalur 1 , jalur 2 dan jalur 3. Kisaran nilai indeks kesamaan jenis yaitu $81-100 \%$ adalah kategori tinggi, 61-80 \% adalah kategori sedang, 41-60 $\%$ adalah kategori rendah, $<40 \%$ yaitu kategori sangat rendah (ShannonWienner Index). Berdasarkan perhitungan Indeks Kesamaaan Jenis (IS) Gastropoda di kawasan hutan, Mangrove Surya Perdana Mandiri dapat dilihat pada dapat 6

Tabel 6. Rekapitulasi Nilai Indeks Kesamaan Jenis Di Setiap Jalur Penelitian (Recapitulation of similarity index values in each research pathway)

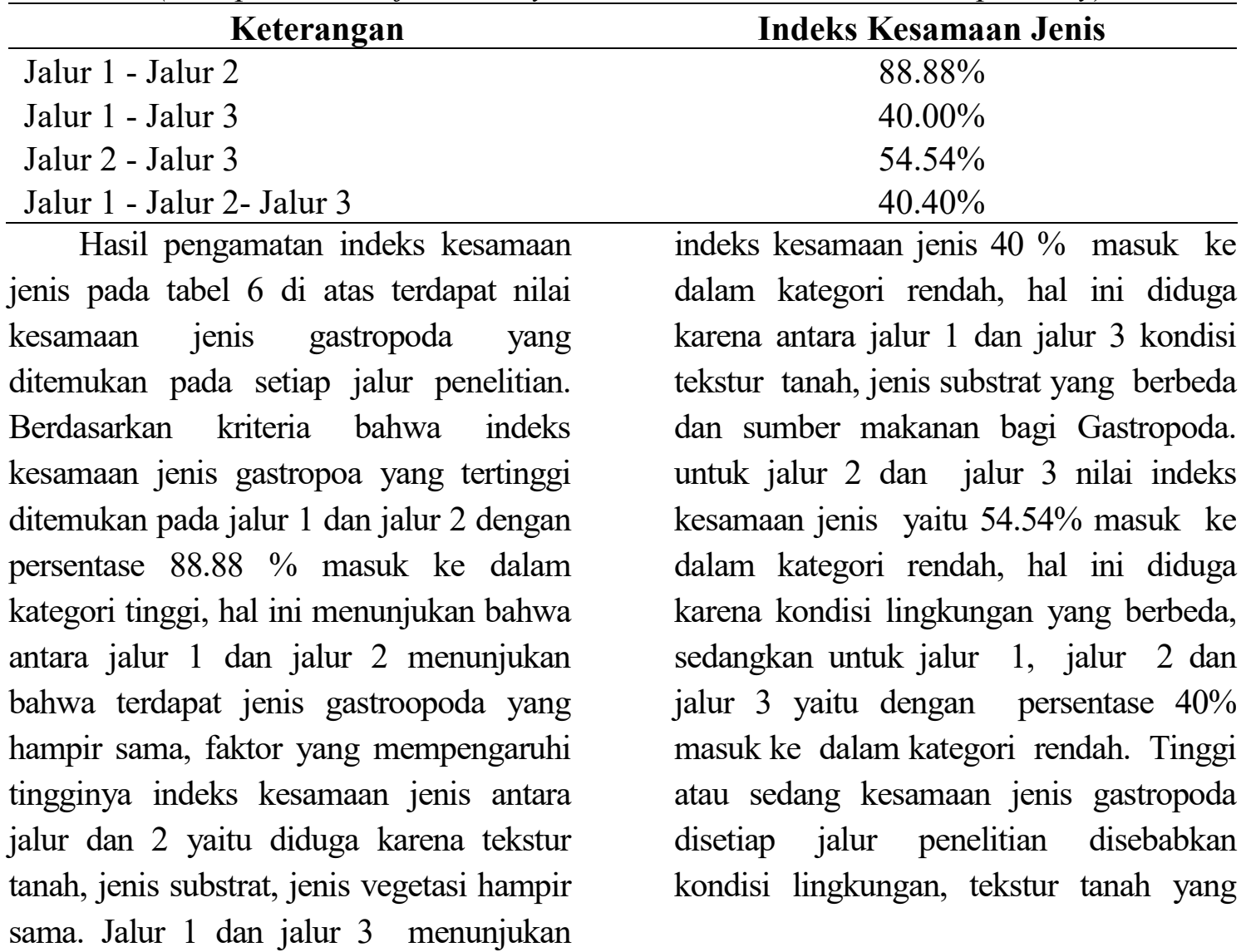


berbeda dan sumber makanan bagi gastropoda.

\section{Kesimpulan}

Berdasarkan hasil penelitian dapat disimpulkan bahwa:

1. Gastropoda yang ditemukan di kawasan hutan mangrove Surya Perdana Mandiri Kelurahan Setapuk Besar Kota Singkawang ditemukan 8 jenis yaitu Littoraria undalata, Littoraria scabra, Spherasminea miniata, Elbium aurisjudge, Cassidula aurifelis, Cerithidea obtusa,Cerithideopsilla alata dan Neritina violacea yang terdiri dari 5 famili yaitu Littorinidae, Assimineidae, Ellobiidae, Potamididae dan Neritidae.

2. Keanekaragaman jenis $\bar{H}$ Gastropoda di setiap jalur penelitian memiliki nilai yang berbeda-beda diantaranya jalur 1 dengan nilai $\bar{H}=0,52$, jalur 2 dengan nilai $\bar{H}=0,56$ dan jalur 3 dengan nilai $\bar{H}=0,62$. Berdasarkan nilai tersebut keanekaragaman jenis $(\bar{H})$ di setiap jalur penelitian dikategorikan memiliki keanekaragaman rendah.

3. Nilai indeks kemerataan jenis (e) jalur $1=0,38$, pada jalur 2 tercatat indeks kemerataan jenis (e) dengan nilai $\mathrm{e}=$ 0,35, sedangkan pada jalur 3 memiliki indeks kemerataan jenis (e) dengan nilai $\mathrm{e}=0,34$. Berdasarkan nilai tersebut dan dibandingkan dengan kriteria yang ada bahwa nilai indeks kemerataan jenis (e) di ketiga jalur penelitian berkisar 0.3-0,6 menunjukkan kemerataan jenis tergolong sedang.
4. Nilai indeks dominansi jalur 1 dengan nilai $(\mathrm{C})=0,35$, jalur 2 $(\mathrm{C})=0,35$ dan jalur $3(\mathrm{C})=0,33$ ini menunjukan bahwa indeks dominansi rendah.

5. Indeks nilai kesamaan jenis (IS) dari hasil penelitian pada jalur 1, jalur 2 dan jalur 3 yaitu antara jalur 1 dan jalur 2 yang mempunyai nilai kesamaan yang tinggi yaitu $88,88 \%$, sedangkan untuk jalur 1 dan jalur 3, jalur 2 dan jalur 3 mempunyai nilai indeks kesamaan jenis rendah.

\section{Saran}

1. Perlu dilakukan kebijakan dalam pemeliharaan ekosistem mangrove di hutan Mangrove Surya Perdana Mandiri sehingga dapat melindungi keanekaragaman jenisGastropoda dan hewan lain yang hidup di dalam ekosistem tesebut.

2. Mengingat akan pentingnya data dan informasi mengenai keanekaragaman jenis Gastropoda di Kawasan Hutan Mangrove Surya Perdana Mandiri Kelurahan Setapuk Besar Kecamatan Singkawang Utara maka diperlukansuatu penelitian lanjutan yang berkesinambungan.

\section{DAFTAR PUSTAKA}

Dharma B. 1988.Siput dan Keong Indonesia (Indonesia Shell). Jakarta: PT.Sarana Graha

Fachrul MF. 2007. Metode Sampling Ekologi. Bumi Aksara: Jakarta.

Ferianita FM. 2007. Metode Sampling Bioekoloogi. Jakarta: Bumi Aksara 
Krebs JC. 1989. Ecological methodology. Harper Collins Publisher, Inc. New York.

Odum PE. 1993. Dasar-Dasar Ekologi. Yogyakarta: UGM-Pers

Nyabakken JW.1992. Biologi Laut. Suatu Pendekatan Ekologis. PT. Gramedia Pustaka Utama. Jakarta (diterjemahkan oleh M. Eidman dkk) 71-71
Nyabakken JW. 1992. Biologi Laut. Suatu Pendekatan Ekologis. Gramedia, Jakarta. (Penerjemah: Eidman dkk. 459)

Nybakken JW. \& Bertness, MD. (2005). Marine Biology an Ecological Approach, 6thedition. San Francisco: Pearson Education, Inc.

Suwignyo.2005. Avertebrata Air Jilid 1. Penebar Swadaya: Jakarta. 